Məmmədov, "Novruz, Azərbaycan-Türkiyə münasibətlərinin mürəkkəbləşməsində maraqlı olan qüvvələr öz məqsədlərinə çatmayacaq", http://www.interfax. az/az/index.php?option=com content\&task=view\&id =37188\&Itemid =9, 05.05.2009;

Memmedyarov, Elmar, (2007), "Hazar Regiyonu için Yeni Yol”, Türk Siyaseti Toplusu, Cilt 6, no 3.

Milliyet, 22.10.2009);

Müsavat gazeti, 02.09.2009.

Nuriyev, Elhan, (2009), “Avrasiya Müasır Geosiyasetinde Azerbaycanın Strateji Rolu”, Azerbaijan Focus, No1 (1), s. 71-81.

Paşayev, Hafiz, (2009), "Globalleşme Devrinde Diplomatların Tahsili", Azerbaijan Focus, No 1 (1), s. 91-101.

President Ilham Aliyev Rreceives Azerbaijani and Armenian Intellectuals, http://www.today.az/news/ politics/53523.html

Ramezanzadeh, Abdollah, "Irans Role as Mediator in Nagorna Karabagh Crisis", Contested Borders in the Caucasus, by Bruno Coppieters (ed.), 1996, VUB University Press, http://poli.vub.ac.be/publi/ContBorders/ eng/ch0701.htm, 12.11.2009.

Ruinten, Sevinç, (2005), Azerbaycan Türk Dövletleri ile Siyasi Elageler Sisteminde, Bakı, Adiloğlu Neşriyat,

Rüstemhanl, Sabir, ANS Televizyonu Xeberler Programı, 02.09.2009.

Sammut, Dennis, (2009), “Müsteqillik Elde Edenden Sonra Azerbaycan'in Harici Siyaseti", Azerbaijan Focus, No: 1 (1), s. 143-151.

Səfər Obiyev: "Azərbaycan Ordusu Qafqazda ən güclü ordudur", http://www.anspress.com/ nid121122.html, 03.10.2009. (Tekrar verilmiş çıkarılmalı)

Statement by H.E. Elmar Mammadyarov Minister of Foreign Affairs of the Republic of Azerbaijan - May 23-25, 2009, Damascus, http://mfa.gov.az/eng/index.php?option=com_content\&task=view\&id= $\underline{567 \& \text { Itemid }=1}, 11.02 .2010$.

Tarnoff, Curt, "The Former Soviet Union and U.S. Foreign Assistance", Congressional Research Service (CRS)Issue Brief for Congress, www.globalsecurity.org/military/library/report/csr/IB95077.pdf, 18.01 .2002

Türkiye Azerbaycan Çalıştayı Raporu, Kafkasya Çalışmaları 2, Temmuz 2009. 
Türkiyə-Ermənistan protokolları Azərbaycanın maraqlarına cavab vermir, http://az. trend.az/news/politics/foreign/1603843.html, 03.01.2010.

Türkiyə-Ermənistanın münasibətlərinə Bakıdan baxış, http://www.voanews. com/azerbaijani/archive/2009-09/Aze-avudturkiyeelxan.cfm? moddate=, 2009- 09 -01

Veliyev, Cavid, "Barışa Uzak Prag Görüşmeleri”, http://www.turksam.org/tr/ yazdir1657.html, 11 May1s 2009.

Xalq Gazeti, 5.12.1997.

Yeni Şafak, 23.04.2009

Yılmaz, Reha ,"Türkiye-Azerbaycan İlişkilerinde Son Dönem”, http://www. bilgestrateji.com/store/dergi2/Reha.pdf, 25.07.2010.

Yılmaz, Reha, "Azerbaycan Dış Siyasetinde Yeni Arayışlar", http://www.usakgundem.com/haber/38544/-yorum-dr-reha-y\%C4\%

B1lmaz-azerbaycan-d $\% \mathrm{C} 4 \% \mathrm{~B} 1 \% \mathrm{C} 5 \% 9 \mathrm{~F}$-siyasetinde-yeni-aray $\% \mathrm{C} 4 \%$

B1\%C5\%9Flar.html, 9 Temmuz 2009.

Y1lmaz, Reha, “Azerbaycan'1 ve Azerbaycanlıyı Anlayabilmek”, USAK Stratejik Gündem, http://www.usak.org.tr/myazdir.asp?id=1043,

Y1lmaz, Reha, "BM Kararı Üzerinden Dağlı Karabağ Problemini Okuyabilmek",http://www.tasam.org/index.php?altid=2204

Zerkala, 29.08.1992. 


\title{
Türkiye'de Lisansüstü Eğitim:Sorunlar ve Çözüm Önerileri
}

\section{Sedat KARAMAN* \& Fehim BAKIRCI **}

\section{Özet}

Temel amacı bilgi üreten, kullanan, eleştiren ve üretken bir düşünce tarzıyla problem çözebilecek nitelikli insan gücünü yetiştirmek olan lisansüstü eğitim; Türkiye'de Üniversitelere bağlı enstitülerce yürütülmektedir. Lisansüstü eğitim; eğitim kalitesi, ülke kaynaklarının etkin kullanımı ve gelişmişlik düzeyi ile yakından ilişkili olduğu için önemle üzerinde durulması gereken bir konudur.

Türkiye'de, lisansüstü eğitimde öğretim üyesi, öğrenci, eğitim programları ve çalışma birimleri ve şartlarıyla ilgili pek çok sorun yaşanmaktadır. Bu çalışma; esas itibariyle lisansüstü eğitimin önemini vurgulayarak, söz konusu bu sorunları genel boyutuyla tespit edebilmeyi ve geliştirilebilecek çözüm önerilerine katkı sağlayabilmeyi amaçlamaktadır.

Anahtar Sözcükler: Lisansüstü eğitim, Enstitüler, Yüksek Lisans, Doktora

\section{POSTGRADUATE STUDY IN TURKEY: PROBLEMS AND PROPOSED SOLUTIONS}

\begin{abstract}
Postgraduate studies aiming to raise qualified human resource able to produce, synthesize and utilize knowledge are carried out by Institutes of Universities in Turkey. Since the postgraduate studies are closely related to quality of education, efficient utilization of country resources and level of development of the country, necessary emphasize should be given for this issue.

There several problems related to instructors, students, educational programs and relevant units of postgraduate studies in Turkey. This study emphasizes the significance of postgraduate studies, specifies the general problems and proposes solutions toward these problems.
\end{abstract}

Key Words: Postgraduate Study, Institutes, Master of Science, Ph.D.

\section{1- GíRiş}

Yaşadığımız bilgi çağında hızla artan ve yayılan bilgi, iş ve meslek hayatında rekabeti güçlendirmiş ve uzmanlaşmayı daha önemli hale getirmiş̧ir.

* Doç. Dr. Gaziosmanpaşa Üniversitesi, skaraman@gop.edu.tr

** Doç. Dr. Gaziosmanpaşa Üniversitesi, fbakirci@gop.edu.tr 
Aynı zamanda ekonominin gerçek sermayesi haline gelen bilginin üretildiği temel birim üniversiteler olmuştur. Toplumun bilimsel araştırma ve yüksek nitelikli insan gücü ihtiyacını karşılamak üzere kurulmuş olan üniversiteler; yüksek düzeyde bilimsel araştırma yapmak, bilgi ve teknoloji üretmek, bilim verilerini yaymak, ulusal ve evrensel gelişmeye katkıda bulunmak gibi oldukça geniş görev, yetki ve sorumluluklara sahip olan kurumlardır. Her alanda toplum yaşamı ile iç içe ve yan yana olan üniversite, eğitim sisteminin en üst kademesinde yer almaktadır. Sistemin diğer kademelerinin görevleri "var olan bilgiyi aktarmak" iken, üniversite esas olarak "bilgiyi üretmek, yaymak ve kullanımını sağlamakla" görevlidir (Tuzcu; 2003).

Mezuniyet sonrası etkin eğitim kademeleri, toplumlarda bilimsel veriler ve teknolojik gelişmelerin bir gereği olarak zamanla artan istek ve zorunlulukla nerede ise iki yüzyıl öncesi uygulanmaya başlanarak, üniversite ve yükseköğrenim kurumlarının birincil amacı haline gelmiştir. Bilimin öğretildiği, öğrenildiği ve üretildiği akademik kurum ve üniversitelerde 19. yy başlarında Almanya'da başlatılan ve geçen iki yüzyıllık süreçte birçok ülkede de yerleşen bu bağ lisansüstü eğitim, öğretim ve araştırma olgularının kenetlenmesini daha da kuvvetli hale getirmiş ve devamını sağlamıştır (Türker; 2001).

Lisansüstü eğitim bilim insanı yetiştirme ve ulusal bilim politikasının yürütülmesindeki en önemli etmenlerden biri olarak kabul edilmektedir. Temel amac1; bilgiyi üreten, kullanan, eleştiren ve üreten bir düşünce tarzıyla problem çözebilecek nitelikte insan gücünü yetiştirmektir. $\mathrm{Bu}$ nedenle lisansüstü eğitimin planlaması ve etkin şekilde yürütülmesi, o ülkenin gelişmişlik düzeyi ile yakından ilgilidir (Alhas; 2006).

Lisansüstü eğitimde; lisans eğitimine göre bireye daha kapsamlı bilimsel araştırmalar yapma, karmaşık sorunları çözebilme, mesleki alanlarda uzmanlaşma, bilgi üretebilme ve sentez yapabilme yöntem ve becerisi kazandırılmaya çalışılır. Günümüzde üniversitelere öğretim elemanı yetiştirmenin dışında, endüstriyel alanlarda ve diğer çalışma alanlarında iş edinmenin bir ön koşulu olarak yüksek lisans ve doktora derecesinin de aranır hale gelmesi, lisansüstü eğitime olan ihtiyacı daha da artırmıştır. Bu ihtiyaca cevap vermek üzere lisansüstü eğitim programları ortaya çıkmıştır. $\mathrm{Bu}$ programlara başvuru ve kabul edilme koşulları üniversiteden üniversiteye bazı farklılıklar göstermekle birlikte hepsinde ortak olan koşul, adayların 
başvurdukları programın gerektirdiği bilimsel yeterliği göstermektir (Demirtaşl1; 2002 - Alhas; 2006).

Üniversite sayısının hızla arttı̆̆ ve her üniversitenin kendi öğretim üyesini yetiştirme çabasına girdiği Türkiye'de, öğretim üyesi, öğrenci ve eğitim programları ve çalışma şartlarıyla ilgili olarak pek çok sorun yaşanmaktadır. Ancak bu sorunlarla ilgili spesifik çalışmalar olmakla birlikte, konunun oldukça az araştırıldığ 1 gözlenmektedir. Sorunların tespiti için gerek öğretim üyesi ve lisansüstü eğitim kurumları, gerekse öğrenci boyutuyla konunun genel ve spesifik olarak araştırılması gerekmektedir. $\mathrm{Bu}$ çalışma; esas itibariyle lisansüstü eğitimin önemini vurgulayarak, söz konusu bu sorunları genel boyutuyla tespit edebilmeyi ve geliştirilebilecek çözüm önerilerine katkı sağlayabilmeyi amaçlamaktadır.

\section{2- TÜRKIYE'DE LİSANSÜSTÜ EĞİTIM}

Lisansüstü eğitim; lisans eğitimine dayalı olan yüksek lisans ve doktora eğitimi ile sanat dallarında yapılan sanatta yeterlik çalışması ve tıpta uzmanlık ile bunların gerektirdiği eğitim, öğretim, bilimsel araştırma ve uygulama etkinliklerinden oluşan eğitim olarak tanımlanır (Sevinç; 2001). Lisansüstü eğitim, üniversitelerde lisans1 izleyen derecelere götüren, araştırma yoluyla bilim ve teknoloji üreten ve ülke kalkınmasına yön çizen bilim insanı yetiştirmeyi amaçlayan, planlı, programlı bir eğitim sürecidir (Varış; 1984). Lisans derecesi ya da diploması almış olanlara ilgi duydukları bilim dalında yüksek lisans ya da doktora öğrenimi yaparak uzmanlaşma olanağı sağlamak üzere düzenlenen lisansüstü eğitim (Oğuzkan; 1981); araştırma yapabilen, üretken, ülke sorunlarına duyarlı, yaratıcı bireyleri yetiştiren eğitim programıdır (Sayan ve Aksu; 2005).

Genel olarak lisansüstü eğitimin araştırma, mesleki gelişim, öğretmeyi öğrenme ve bunlara bağlı mesleki kültür, akademik kültür ve etik konularını en üst sosyal, bilişsel ve işitsel düzeylerde edinme süreci olduğu söylenebilir (İnce ve Korkusuz; 2006). Başka bir anlatımla lisansüstü eğitim bir alanda derinlemesine çalışarak lisans eğitiminden daha üst düzeyde bilgi ve etkinliğe sahip olan yüksek ihtisas gücünü yetiştiren eğitim programı olarak tanımlanmıştır. Buna göre lisansüstü eğitimin araştıran, bilim üreten ve aydınlatan bir bilim insanı, yalnızca mevcut bilgiyi aktaran değil yeni bilgileri araştıran, analiz eden ve bunları öğrencilerine aktaran bir öğretim üyesi, kendi alanında mevcut çalışmaları bilen, yeni bulgulara ulaşmak ve bunları yaymak 
için çalışan ve bulgularını yayan araştırmacı yetiştiren bir eğitim faaliyeti olduğu belirtilmiştir (Çakar, 1997 - Alhas; 2006).

Lisansüstü eğitim, fakültelerde verilen dört y1llık eğitimin ardından kavramsal düzeyde lisans derecesi veya diploması alan öğrencinin, lisans eğitiminde alınan disiplin konusunda veya ilgi duyduğu bilim dalında enstitüler tarafından verilen eğitimle yüksek lisans (bilim uzmanllğı) veya doktora öğrenimi yaparak uzmanlaşma olanağı sağlayan ve toplumların gereksinim duyduğu bilim insanı, araştırmacı ve yüksek nitelikli insan gücünü yetiştirmek için oluşturulmuş üst düzey bir eğitim programı sürecidir.

Üniversite; Bilimsel özerkliğe ve kamu tüzel kişiliğe sahip, yüksek düzeyde eğitim, öğretim, bilimsel araştırma, yayın ve danışmanlık yapan, fakülte, enstitü, yüksekokul ve benzeri kuruluş ve birimlerden oluşan bir yükseköğretim kurumudur (2547 Sayılı YÖK Kanunu, 3/d. Maddesi).

Enstitü; Üniversitelerde ve fakültelerde birden fazla benzer ve ilgili ana bilim dallarında lisansüstü eğitim-öğretim, bilimsel araştırma ve uygulama yapan bir yükseköğretim kurumudur (2547 Sayılı YÖK Kanunu, 3/f. Maddesi). Söz konusu bu eğitim ve öğretim faaliyetleri genellikle üniversiteler bünyesindeki fen bilimleri, sosyal bilimler, sağlık bilimleri, eğitim bilimleri vb. enstitüler tarafindan yürütülür. Bunların dışında yine benzer şekilde özel bir uzmanlık alanında yüksek öğretim faaliyeti yürütmek maksadıyla kurulmuş; AB Araştırmaları Enstitüsü, Türkoloji Enstitüsü gibi enstitüler de olabilir. Bu tür enstitülerde özel araştırma ve uygulamalar yürütülebilmektedir.

$\mathrm{Bu}$ enstitülerden Fen Bilimleri Enstitülerinde; üniversitelerin fen, mühendislik, mimarlık, ziraat ve orman fakültelerinin bölümleri ile fen edebiyat fakültelerinin fen eğitimi ve müzik eğitimi bölümleri, Teknik Eğitim Fakültelerinin bölümleriyle ilgili ana bilim dalları bulunmaktadır (Karakütük; 2002).

Sosyal Bilimler Enstitülerinde ise, iktisadi ve idari bilimler, siyasal bilgiler, eğitim ve fen edebiyat gibi fakültelerinin sosyal bilimler alanına giren bölümlerinin ana bilim dalları bulunmaktadır. Eğitim fakültelerinin yüksek eğitimini eğitim bilimleri enstitülerinin verdiği özel durumlar da bulunmaktadır.

Tıp ve yardımcı sağlık hizmetleriyle ilgili yüksek öğretim programları da sağl1k bilimleri enstitüleri tarafından yürütülmektedir.

Yüksek Lisans; Bir lisans eğitimine dayalı eğitim-öğretim ve araştırmanın sonuçlarını ortaya koymayı ve ilgili konularda bilimsel yöntemleri kullanabilme 
kabiliyeti geliştirilerek, uzmanlık alanı oluşturabilecek şekilde eğitim ve araştırma faaliyetlerini sürdürmeyi amaçlayan bir yüksek eğitim programıdır.

Doktora; Lisansa dayalı en az altı veya yüksek lisansa, Eczacılık ya da Fen Fakültesi mezunlarınca Sağlık ve Sosyal Yardım Bakanlığı tarafından düzenlenen esaslara göre bir laboratuar dalında kazanılan uzmanlığa dayalı en az dört yarıyıllık programı kapsayan ve orijinal bir araştırmanın sonuçlarını ortaya koymayı amaçlayan bir eğitim programıdır.

Tipta uzmanlık: Sağlık Bakanlığı tarafından düzenlenen esaslara göre Sağlık Bakanlığı, üniversiteler, Sosyal Sigortalar Kurumu ile diğer kurumların eğitim ve araştırma hastanelerinde yürütülen ve tıp doktorlarına belirli alanlarda özel beceri kazandırmayı ve yetki sağlamayı amaçlayan programdır.

Sanatta yeterlik: Lisansa dayalı en az sekiz yarıyıllık, yüksek lisansa dayalı en az dört yarıyıllık programı kapsayan ve özgün bir sanat eserini ortaya koymayı, müzik ve sahne sanatlarında ise üstün bir uygulama ve yaratıcılığ1 amaçlayan doktora eş değeri bir programdır.

Bilimsel Hazırlık Programı: Başvurdukları programın bir alt düzeyindeki diplomalarını farklı alanlarda ya da farklı bir yükseköğretim kurumunda almış olan adayların, ilgili programın asıl süresi dışında bir yıllık hazırlık eğitimi aldıkları programdir.

Lisansüstü eğitim yüksek lisans, doktora, tıpta uzmanlık ve sanatta yeterlik eğitimini kapsar. Öğrenciler, lisans eğitimlerinde edinmedikleri özel becerileri ve bilgileri yüksek lisans programlarında edinmek üzere eğitim görürler. Yüksek lisans derecesi giderek uygulamaya yönelmek isteyen öğrencilere özgü bir seçeneğe dönüşmekte, doktora eğitimi alabilmenin koşulu olmaya da devam etmektedir. Günümüz akademik ortamında, akademik unvana sahip bir pozisyonda çalışabilmek, öğretim verebilmek ve araştırma yapabilmek içinse doktora derecesi ön koşul durumuna gelmiştir (Yılmaz, 2008). Doktora eğitim programında hazırlanan tezin bilime yenilik getirme, yeni bilimsel yöntem geliştirme, bilinen yöntemi yeni bir alana uygulama ve benzeri özellikleri taşıması gerekir (Çakar, 1997). Doktora programıyla akademik çalışma düzeyinde alanda gerek duyulabilecek bilimsel nitelikli araştırmaları kurgulayabilecek, yönetebilecek ve sonuçlandırabilecek özellikli araştırmalar ve araştırmacılar yetiştirilmesi amaçlanmaktadır (Can vd.; 2009). Bu açıklamalardan anlaşıldığı gibi yüksek lisans eğitimi lisans düzeyinde öğrenilen temel bilgilerin sentez yapıldığı bir basamak, doktora eğitimi ise lisans ve 
yüksek lisans düzeyinde kazanılan bilgilerin birleştirildiği ve bilimsel eserin ortaya çıkarıldığ 1 bir basamaktır (Gök ve Sılay; 2005). Yüksek Lisans Eğitiminin amacı öğrenciye bilimsel araştırma yaparak bilgilere erişme, bilgileri değerlendirme ve yorumlama yeteneğinin kazanmasını sağlamaktır. Doktora eğitiminin amacı ise "öğrenciye bağımsız araştırma yapmak, bilimsel olayları geniş ve derin bakış açısı ile irdeleyerek yorum yapmak ve yeni sentezlere ulaşmak için gerekli adımları belirleme yeteneği kazandırmaktır.

Lisans eğitimine dayalı olarak yüksek lisans eğitimiyle yetiştirilen "bilim uzmanı" bilim insanı olma yolunda ilk basamaktadır. Bilim uzmanı, yüksek lisans eğitimi alırken uzmanlık yaptığı bilim alanına özgü bilgi, tutum ve becerilerin yanı sıra özellikle tez yaparken kullanacağı araştırma teknik yeterlikleri, bilimsel tutum ve davranışları kazanmalıdır. Eğitim üyesi yüksek lisans eğitimiyle bilim uzmanı yetiştirirken araştırma teknik yeterliklerinin, bilimsel tutum ve davranışların teorik ve uygulamalı eğitimle kazandırılmasına özel bir önem vermelidir (Erdem; 2007).

Yüksek lisans eğitimine dayalı olarak doktora eğitimiyle yetiştirilen "bilim doktoru", bilim insanı olma yolunda ikinci ve en önemli basamaktadır. Doktora orijinal bir araştırmanın sonuçlarını ortaya koymayı amaçlayan programdır. Doktora programı da kendi içinde doktora, tıpta uzmanlık ve sanatta yeterlik diye üçe ayrılır (Karakütük; 2002).

Türkiye'de lisansüstü eğitim, 1960'ların sonlarına kadar yüksek lisans aşaması olmaksızın yalnızca doktora programı şeklinde 3-4 yıllık lisansüstü eğitimle hoca-asistan (bir anlamda usta-çırak) ilişkisi esasına göre yürütülmüştür. 1970'lerden itibaren önce "yüksek lisans" ve daha sonra "doktora" olmak üzere iki aşamaya bölünmüş ve bu aşamalarda izlenecek yöntem ve kurallar günümüze kadar pek çok kere, tümüyle ya da kısmen değiştirilen yönetmelikler doğrultusunda sürdürülmüştür (Çakar; 1997).

2547 sayılı Yüksek Öğretim Kanununun amac1; yükseköğretimle ilgili amaç ve ilkeleri belirlemek ve bütün yükseköğretim kurumlarının ve üst kuruluşlarının teşkilatlanma, işleyiş̧, görev, yetki ve sorumlulukları ile eğitim öğretim, araştırma, yayım, öğretim elemanları, öğrenciler ve diğer personel ile ilgili esasları bütünlük içinde düzenlemektir. Yüksek Öğretim Kanunu ve İlgili Mevzuat'a göre lisansüstü eğitim, 2547 sayılı Yüksek Öğretim Yasasının 65. maddesi hükmü gereğince Üniversiteleraras1 Kurulca hazırlanan "Lisansüstü Eğitim ve Öğretim Yönetmeliği" ile düzenlenmiştir. 
Türkiye'de lisansüstü eğitim 1982 yılından itibaren Yüksek Öğretim Kurulunun bağlı olarak yasada yer alan enstitüler aracılığıyla yürütülmektedir. Lisansüstü eğitim, üniversiteler içinde örgütlenecek şekilde lisansüstü eğitimin organize edilmesi ve yürütülmesi amacı ile kurulan ve 2547 sayılı Yüksek Öğretim Kanunun ile yürürlüğe giren enstitülerce düzenlenmiş olup üslendikleri görevler, belirli çerçeve ve yönetmeliklerle belirlenmiştir.

2547 sayılı Kanun'un 19. Maddesi gereğince, rektörlüklere bağlı enstitülerin yapılarını oluşturan enstitü ana bilim ve enstitü ana sanat dalları aşağıdaki şekilde belirlenmektedir.

a) Fen Bilimleri Enstitüsünün enstitü ana bilim dalları, o üniversitede mevcut olan Fen, Mühendislik, Mimarlık, Mühendislik-Mimarlık, Gemi Ínşaatı ve Deniz Bilimleri, Maden, İnşaat, Elektrik-Elektronik, Makine, KimyaMetalürji, Uçak ve Uzay Bilimleri, Ziraat, Orman, Su Ürünleri, Denizcilik Fakültelerinin bölümleri; Fen-Edebiyat, Endüstriyel Sanatlar Eğitim ile Eğitim Fakültelerinin Fen alanındaki bölümleri, Mesleki Eğitim Fakültelerinin Teknoloji Eğitimi bölümüyle aynı adları taşırlar. Fakültelerin bölüm başkanları aynı zamanda enstitü ana bilim dalının da başkanıdırlar.

b) Sosyal Bilimler Enstitüsünün enstitü ana bilim ve enstitü ana sanat dalları, o üniversitede mevcut olan Edebiyat, İktisat, İşletme, İktisadi ve İdari Bilimler, Siyasal Bilgiler, Hukuk, İlahiyat, Dil ve Tarih-Coğrafya, Güzel Sanatlar, İletişim, Mesleki Yaygın Eğitim, Ticaret ve Turizm Eğitimi, Eğitim Bilimleri Fakülteleri ile Konservatuarların bölümleri; Fen-Edebiyat, İnsani Bilimler ve Edebiyat, Mesleki Eğitim ve Eğitim Fakültelerinin Fen alanı dışındaki bölümleriyle aynı adları taşırlar. Fakültelerin ve Konservatuarların bölüm başkanları, aynı zamanda enstitü ana bilim veya enstitü ana sanat dalının da başkanıdırlar.

c) Sağlık Bilimleri Enstitüsünün enstitü ana bilim dalları, o üniversitede mevcut olan Tıp, Diş Hekimliği, Eczacılık ve Veteriner Fakültelerinin eğitim yapılan ana bilim dalları ile Eğitim Fakültelerinin beden eğitimi ve spor bölümleridir. $\mathrm{Bu}$ ana bilim dallarının başkanları ile beden eğitimi ve spor bölüm başkanları aynı zamanda Sağlık Bilimleri Enstitüsünün ana bilim dallarının da başkanlarıdır.

d) Fen Bilimleri, Sosyal Bilimler ve Sağlik Bilimleri Enstitülerinde, rektörün önerisi ve Yükseköğretim Kurulu kararı ile lisansüstü eğitim yapmak üzere, bir fakülte, bölüm veya ana bilim dalından değişik bir ad taşıyan, 
disiplinler arası bir enstitü ana bilim dalı kurulabilir. Bu tür bir enstitü ana bilim dalının başkanı, ilgili dekanların görüşleri alınarak, Enstitü Müdürü tarafindan atanir.

e) Fen Bilimleri, Sosyal Bilimler ve Sağlık Bilimleri Enstitüleri dışında kalan, rektörlüklere bağl1 enstitülerin enstitü ana bilim ve enstitü ana sanat dalları, bu enstitülerin özellikleri dikkate alınarak, Yükseköğretim Kurulu tarafindan tespit edilir. $\mathrm{Bu}$ enstitülerde, enstitü ana bilim ve enstitü ana sanat dalları başkanları Enstitü Müdürü tarafından atanır.

Lisansüstü eğitimin, yurt içi ve yurt dişı programlar olmak üzere iki kaynağı bulunmaktadır. Türkiye'de, 1929 tarihli 1416 sayılı yasa ve 1981 tarihli 2547 sayılı yasa çerçevesinde lisansüstü eğitim için yurt dışına öğrenci gönderilmektedir. 1416 sayılı yasa, gereksinim duyulan alanlarda yurt dişında yüksek nitelikli insan gücü yetiştirmeye ilişkin ilk yasal düzenlemedir. 2547 sayılı yasa ise yalnızca üniversiteler için öğretim üyesi yetiştirmeyi amaçlamaktadır. Bu iki yasa dışında da lisansüstü eğitim için yurt dışına öğrenci gönderilmektedir. TÜBİTAK, TÜBA vb. kuruluşların sağladıkları burslar, ülkeler arasındaki kültürel değişim programları çerçevesindeki burslar (Fullbright vb), uluslararası kuruluşların (UNESCO, NATO vb.) sağladığı burslar örnek olarak verilebilir. Ayrıca DPT vb. kurumların uzman insan gücü yetiştirmek üzere sağladıkları kurumsal kaynaklar bulunmaktadır (Tuzcu; 2003).

\section{3- ÜNIVERSITELER VE LISSANSÜSTÜ EĞİTIMIN ISSLEVLERİ}

Yüksek öğretim kurumlarının toplumun her kesimi için nitelikli iş gücünü yetiştirme, bilim ve teknoloji üretme, toplumu aydınlatma, toplumsal değişme ve gelişmelere önderlik etme gibi görevleri yerine getirmesi beklenir. Bu nedenle yüksek öğretim, ülkeler için itibar sembolü olmuştur (Kaya; 1989).

Enstitüler, üniversitelerde ve fakültelerde birden fazla benzer ve ilgili bilim dallarında lisansüstü eğitim, öğretim, bilimsel araştırma ve uygulama yapan, yayın etkinliklerini sürdüren yükseköğretim kurumlardır. Bu kurumlar bağlı oldukları üniversitenin genel anlayışları doğrultusunda bilimde ufuk açacak, bilgi hazinesine yenilerini katacak lisansüstü çalınmaların nasıl olması gerektiği konularında kurallar koyarlar (Yılmaz; 2008).

Enstitülerin temel işlevleri bilim adamı yetiştirmek, üniversiteye, serbest iş sektörlerine, sanayi ve üretim merkezlerine bilimsel ölçütlere göre eğitilmiş elemanlar yetiştirmek, bilimsel araştırma yaptırmak ve uygulamaktır. Bir başka 
anlatımla enstitüler, bilimsel kalkınmayı hedef edinerek üniversitenin lisansüstü eğitim ve araştırma olanaklarını değerlendiren, etkili hale getiren, aynı zamanda meslek sahiplerine ve hatta uzmanlara yeni bir alanda teorik-pratik beceri kazandıran ya da düzenli ve zorunlu programlar açarak diplomalarının güncelliğini koruyan kurumlardır. Enstitülerden ayrıca, lisansüstü eğitim olanaklarını uluslararası düzeyde değerlendirerek yurt dışında da etkinlik göstermeleri beklenir (Türker; 2001, Tosun; 2001, Y1lmaz; 2008).

Günümüzde üniversitelerin işlevleri, hızla değişen ve artan bilgi birikimi karşısında değişmek zorunda kalmıştır. İstenilen yüksek nitelikli insan gücü artık lisansüstü düzeyde eğitimle yetiştirilmeye başlanmıştır. Önceleri lisans mezunu olmak ayrıcalıklı sayılırken, şimdilerde yüksek lisans ya da doktora eğitimi bireye ayrıcalık sağlamaktadır (Güven ve Tunç; 2007- Kara; 2008). Lisansüstü eğitimin işlevleri, üniversitelerin işlevleri ile paralellik göstermektedir. Bilim ve sanat üretmek, yaymak, toplumsal sorunları doğru algilamak ve sorunlara çözüm önerileri geliştirmek ve üst düzey insan gücünün yetiştirilmesine katkıda bulunmak şeklinde belirtilebilecek bu işlevler doğrultusunda, lisansüstü eğitimin önemi günümüzde giderek artmaktadır (Arıc1; 2001). Lisansüstü eğitimin niteliği üniversitenin niteliğini, üniversitenin niteliği ise giderek toplumun niteliğini etkilemektedir. Disiplinler arası niteliği olan eğitim sistemlerinde her türlü uzman ve akademisyenin lisansüstü eğitim kademesinde yetiştiriliyor olması konuyu daha da önemli kılmaktadır (Demirtaşl1; 2002). Temel yapısı araştırma ve eğitimi birlikte yürütmeye ve bilimsel üretime katkıda bulunmaya dayalı olan lisansüstü eğitimin işlevleri, üniversitelerin temel işlevleriyle benzerliği yönünden şöyle özetlenebilir (Arıc1; 2001, Tosun; 2001, Y1lmaz; 2008).

- Bilim/Sanat Üretme ve Yayma: Geleneksel olarak üniversitelerden beklenen hizmetlerin başında araştırma-geliştirme çalışmaları yoluyla yapılan bilim üretmek ve bunu yaymak gelir. Bu gibi çalışmaların bilime/sanata katkı getirip getirmediği ve yapılan katkının derecesi, bilimin/sanatın eleştirili ve ayıklayıcı süreçleriyle belirlenebilir.

- Toplumsal Sorunlari Doğru Algilama ve Sorunlara Çözüm Önerileri Geliştirme: Üniversitelerin ikinci işlevi toplumların idealleri ve değerleri ile yaşadığı olayların, teknolojik, ekonomik ve kültürel gelişimleri ile ilgili sorunların ve beklentilerin doğru algılanmasında ve tanımlanmasında ve yaşanan sorunlara gerçekçi çözüm önerileri geliştirerek bunları uygulamaya 
aktarmada yardımcı olmaktır. Bunu sağlamanın bir yolu, lisansüstü örgencilerinin üniversiteler dışındaki özel ve kamu kurum ve kuruluşlarında çalışanlardan oluşmasıdır. Yani lisansüstü eğitim programlarını olanaklar ölçüsünde üniversite dışına açmaya özen göstermektir.

- Üst düzey insan gücünün yetiştirilmesine katkıda bulunma: Yükseköğretim kurumlarının önemli bir işlevi, geleceğin öğretim üyelerini ve araştırmacılarını yetiştirmektir. Bağımsız araştırmacılar yarının değerler dizisi ve ürünleri için gerekli altyapı çalışmalarını yapacak ve geleceğin öğretim üyeleri ile araştırmacılarını eğiteceklerdir. Diğer işlevi, bilim üretiminde ve bilimin yayılmasında fiilen görev alacaklar yanında, özel ve kamu hizmetlerini üst düzeyde düzenleyip yürütecek, toplumun üretim ve hizmet etkinliklerinin nicelik ve niteliğini yükseltecek insan gücünün yetiştirilmesine de katkıda bulunmaktır.

Mezuniyet sonrası eğitimi kapsayan lisansüstü eğitimin ülkemiz bilim insanlarının yetiştirilmesi yönünden ne kadar önemli olduğu açıktır. Bilim insanı, yüksek mühendis, araştırmacı, yüksek nitelikli insanların yetiştirilmesi, belirli bir bilimsel konuda bağımsızlığı ve yetkinliği kazanmak amacıyla yapılan lisansüstü eğitimle olanaklıdır.

En üst eğitim ve araştırma kurumları olan çağdaş üniversitelerin en önemli işlevi olan lisansüstü eğitim; nitelikli lisans eğitimini sağlaması, bilim ve tekniğin ilerlemesini ve araştırmaların yapılmasını sağlaması, bilgiyi üretmesi ve yayması, bilimsel düşünceyi geliştirmesi, üst düzeyde eğitim sağlaması, araştırma geliştirme etkinliklerine katkıda bulunması, teknik alanda gelişme sağlamaya yönelik araştırmalar yapılmasını sağlaması, ülke sorunlarına çözüm olanakları sunması, geleceğin öğretim üyelerini ve araştırmacılarını yetiştirmesi, ülke kalkınması için gerekli serbest piyasadaki iş alanlarına, sanayi ve üretim merkezlerine yeterli nitelikli insan gücünü yetiştirmesi gibi önemli görevleri gerçekleştirmektedir. Lisansüstü eğitim, ülkelerin hedefledikleri amaçları gerçekleştirmelerinde katkı sağladığ 1 gibi teknolojik, ekonomik ve kültürel gelişimleri ile ilgili sorunlarına çözüm getirmektedir.

Lisansüstü eğitim; bir alanda derinlemesine çalışarak lisans eğitiminden daha üst düzeyde bilgi ve etkinliğe sahip yüksek ihtisas gücünü yetiştiren eğitim programıdır. Her ne kadar işlevleri farklı da olsa amaç, "bilim insanı, öğretim üyesi ve araştırmacı" yetiştirmektir (Çakar; 1997). Bu bağımsız araştırmacılar yarının paradigmaları ve ürünleri için gerekli altyapı çalışmalarını yapacak ve 
geleceğin öğretim üyeleri ile araştırmacılarını eğiteceklerdir (Tosun, 2001). Ancak lisansüstü eğitimi bitiren herkese geleceğin bilim insanı gözüyle bakmak, dünyadaki gelişmeler karşısında pek doğru görünmemektedir. Üniversitenin yüksek nitelikli araştırma yapabilecek insan gücüne gereksinimi olduğu kadar, sanayinin de yetişmiş insan gücüne gereksinimi bulunmaktadır. Kalkınma sürecini hızlandırmak, hem özel sektörde hem de kamu sektöründe bilimsel araştırma yapmayı gerekli kılmaktadır (Alhas; 2006).

Lisansüstü eğitim, bilim alanında yetkinleşme ve uzmanlaşma açısından dünyada zorunluluk haline gelmiştir. İş gücü piyasalarının, birçok alanda olduğu gibi kendisi için iş gücünü hazırlayan eğitim kurumları üzerinde etkileri açıkça görülmeye başlanmıştır. İş gücü piyasasında kendilerine yer elde etmeye çalışan bireyler, aranan bir iş gören olabilmek için iş gücü talebinde sürekli uzayan kuyruğun başına geçme çabası içindedirler. Lisans düzeyinde mezun sayısının artması, bireyleri daha ileri eğitim düzeylerine ve daha farklı niteliklerle donanmaya yönlendirmektedir. $\mathrm{Bu}$ anlamda lisansüstü eğitim, bireyin gelecekteki gelirini ve sosyal statüsünü artırmaya yönelik yaptığı bir yatırım olarak görülebilir (Bülbül; 2003).

Yoğunlaşan rekabet koşullarının belirleyici unsuru yüksek nitelikli insan gücü olduğundan, yüksek nitelikli yükseköğretim talebi de hızla artmaktadır. 21. yüzyılda yükseköğretim, kitlesel eğitim yapmakla birlikte esas olarak uluslararası rekabet gücüne sahip insan gücü yetiştirmeye odaklanacaktır (Tuzcu; 2003). Lisansüstü eğitime olan talep ve bu eğitimin topluma yararlı olması konusundaki beklentilerin gün geçtikçe arttı̆̆1 bu eğitim sürecinde, öğrencilerden alanları ile ilgili özgün bilimsel araştırma yapma ve öğretmeyi öğrenme becerilerini geliştirmelerinin yanı sıra, akademik kültür, sorumluluk ve etik değerleri benimseme özelliklerini de edinmeleri beklenmektedir. Literatürde bu sürecin, verimliliğin artmasındaki en önemli etkenin öğrenci ve öğretim üyesi arasındaki etkileşimin biçimi ve niteliği olduğu belirtilmektedir (İnce ve Korkusuz; 2006).

Toplumun gereksinimi olan, özellikle yükseköğretimde ve bilimde seçkinler, gelişmiş üniversitelerdeki doktora programlarıla yetiştirilebilmektedir. Lisansüstü eğitim, yükseköğretimde eğitim ve araştırma bütünlüğünü daha kuvvetli hale getiren ve sürdüren bir bağdır. Lisansüstü programlar ve özellikle doktora programlarıyla kişilere bağımsız araştırma 
yapma, bilimsel olayları geniş ve derin bakış açısı ile irdeleyerek yorumlama ve yeni sentezlere ulaşma yeteneği kazandırılmaktadır (Tuzcu; 2003).

Bütün bu açıklamalardan yola çıkarak lisansüstü eğitimin ülkelerin hedeflediği nitelikli insan gücü kaynağının yetiştirilmesinde, bilim ve sanat üretmede ve toplum sorunlarının çözülmesinde önemli katkısı olduğunu söylenebilir (Nayır; 2007).

Türkiye'de Lisansüstü eğitimin gelişmesini sağlayan ve bugün yüksek öğrenimin önemli kademesi durumuna getiren başlıca etkenler şunlardır.

- Düşünen, araştıran, sorgulayan, fikir üreten, bilgi alışverişinde bulunan, çevresiyle ilişki kurabilen, yabancı dil bilen kendine güvenen, nitelikli bireylerin kazandırılması,

- Ülkemizin kalkınması için yüksek nitelikli insan gücüne duyulan gereksinim,

- Lisansüstü eğitim gören iyi yetişmiş, kariyer yapmış serbest piyasanın gereksinimi olan yüksek nitelikli öğrencilerin daha kolay iş bulmaları,

- Bilimsel ve teknolojik gelişmelerin hızlı gelişmesi ve bunda üniversitenin önemli rol oynaması,

- Teknolojideki hızlı gelişimin lisans eğitiminden sonra da eğitimi gerekli k1lmas1,

- Üniversiteler ve öğrenci sayılarındaki artış nedeniyle öğretim üyesine ve nitelikli elemana olan gereksinimin artması.

- Lisans öğrenimini tamamlayan meslek sahiplerinin bilgilerini yenileme gereksinimi, Lisansüstü eğitimini tamamlayan kamu çalışanlarının kademederece ilerlemesinin sağlanması,

- Bazı kuruluşlarda yönetici olmak için lisansüstü eğitiminin tamamlanmış olma koşulunun aranması,

- Bilimsel düşüncenin geliştirilmesi, bilginin üretilmesi ve yayılması.

\section{4- LİSANSÜSTÜ EĞİTIMIN SORUNLARI VE ÇÖZÜM ÖNERILERI}

Türkiye'deki en üst eğitim ve araştırma kurumu olan üniversitelerde yapılan lisansüstü öğrenimde öğretim üyesi sorunu, mali sorunlar, kütüphane hizmet sorunları, yabancı dil sorunu, yönetsel sorunlar, tez danışmanıyla ilgili sorunlar, araç gereç sorunları vb. sorunlar bulunmaktadır. Yaşanan bu sorunlar 
lisansüstü programlarda eğitim gören öğrencilerin ürettiği tezlerde, ilgili içerik ve yöntem sorunlarını beraberinde getirebilmektedir.

- Yetersiz öğretim üyesi sayısı özellikle gelişmekte olan üniversiteler için önemli bir sorundur. Lisansüstü eğitimin daha nitelikli öğretim üyesi gerektirmesi, yeni kurulan ve yeterince gelişmemiş üniversitelerin yetersiz kadro ile lisansüstü eğitim vermeye çalışması lisansüstü eğitimin kalitesini düşürmektedir. $\mathrm{Bu}$ amaçla gelişmekte olan üniversitelerin öğretim üyesi gereksiniminin karşılanması, gelişmiş üniversitelerin programlarından yararlanılması, yüksek nitelikli ve yeter sayıda öğretim elemanı yetiştirmek için önlemler alınması yoluna gidilmelidir.

- Öğretim üyelerinin lisans düzeyinde haftalık ders yüklerinin çok fazla olması, tez danışmanlığı yapan öğretim elemanlarına düşen öğrenci sayılarının fazla oluşu ve öğrenciye yeterli zaman ayıramaması, tez danışmanlığına atamada nitelikli öğretim üyesi koşulu aranmaması gibi etkenler lisansüstü eğitimin kalitesini düşürmektedir. Çünkü öğretim üyesinin niteliği lisansüstü eğitimi yönünden önemlidir. Lisansüstü eğitim yapan üniversitelerde görev yapan öğretim elemanlarının belirli niteliklere sahip olması gerekmektedir.

- Enstitüler mali olanaklar yönünden yetersiz olup kısıtlı ödeneklere sahip olmakta, destek alamamakta, ödenek yokluğu, alt yap1 eksikliği sorunları ile karşı karşıya kalmaktadırlar. Bağımsız bir mekana sahip olmayan enstitüler çok az sayıda personel ile hizmet vermektedir.

- Pahalı ve yüksek maliyetli lisansüstü eğitimde kitap, kırtasiye, fotokopi, yol vb. harcamaları yapmak zorunda kalan öğrenciler maddi sorunlarla karşılaşmakta yeterince verimli olamamaktadır. Bu nedenle pahalı ve yüksek maliyetli olan lisansüstü eğitimin gerekli olanakların ve donanımın sağlandığ enstitülerde yapılması sağlanmalı ve lisansüstü öğrencilerine tez çalışmalarında destek verilmelidir. Lisansüstü öğrencilerinin maddi sorunları projelerle çözümlenmesi sağlanmalı, burs ve istihdam sorunları çözümlenmeli, kamuda işe girerken öncelik tanınmalıdır.

- Lisansüstü eğitimde gerekli olan araç, gereç ve laboratuar olanaklarının bulunmaması, bunun için öğrencilerin kendi olanaklarının kullanımının zorlanması, diğer üniversitelerin laboratuarlarından yararlanmak zorunda bırakılmalarına neden olmaktadır. Üniversitelerin enstitüleri bünyesinde Yüksek Lisans ve Doktora programlarının açılması için belirli sayıda öğretim üyesi bulunma koşulu ve yeterli finansmana sahip olması, laboratuar, bilgisayar, 
kütüphane vb. gibi lisansüstü eğitim için gerekli olan her türlü alt yapının olanaklarının sağlanması gerekir.

- Lisansüstü öğrencilerin eğitim sürecinde bilginin paylaşıldığı ortamlar olan kongre ve sempozyum gibi bilimsel toplantılara katılımlarının en az düzeyde gerçekleşmesi sorunu, kendilerini geliştirmeleri ve yenilemelerini engellemektedir. $\mathrm{Bu}$ nedenle lisansüstü eğitim yapan öğrencilerin yurtiçi ve yurtdışındaki bilimsel toplantılara katılımı teşvik edilmeli ve desteklenmelidir.

- Lisansüstü eğitim yapan üniversitelerin çoğunda kütüphanelerin hizmet ve kapasite olarak yetersiz olması, çalışma ve araştırmaya yeterli olanak sağlayamaması önemli sorundur.

- Bazı üniversitelerin enstitüleri yüksek lisans başvurularında yabancı dil koşulunu istememektedir. Oysa lisansüstü eğitimin birçok alanında araştırmaların ve Türkçe kaynakların yetersiz olması, yabancı dil bilgisini zorunlu kılmaktadır. Öğrencilerin yabancı dil sorunları, tez çalışmalarındaki verimliliği düşürmektedir. $\mathrm{Bu}$ nedenle lisansüstü eğitim yapacak olan öğrencilerin lisansüstü öğrenime başlamadan önce yabanc1 dil bilgilerinin yeterli düzeyde olmasının sağlanması, bunun için gerekli önlemlerin alınması sağlanmalıdır. Enstitülerde öğrencilerin lisansüstü öğrenimine başlamadan önce yabancı dil ön koşul olarak kabul edilmelidir. Günümüzde doktora öğreniminde tez aşamasına geçmeden önce ÜDS den önceden belirlenmiş bir puanın alınması istenmektedir. Ders aşamasını geçen ancak gerekli puanı alamayan öğrenci tez aşamasına geçememekte enstitü ile ilişkisi kesilmektedir.

- Enstitüler arasında yapısal ve işleyiş ile ilgili farklılıkların bulunması önemli sorundur. Üniversitelerin enstitüleri arasında Akademik Personel ve Lisansüstü Eğitimi Giriş Sınavı (ALES) ve Üniversitelerarası Kurul Yabancı Dil Sınavı (ÜDS) ile ilgili ön şartlar ve yönetmelik farklılıkları gibi farklı uygulamalar bulunmaktadir.

- Enstitülerde lisansüstü programlar çok kolay açılmakta, bunun için fazla sayıda öğretim üyesine gerek duyulmamaktadır. Koşullar uysun veya uymasın her üniversitede lisansüstü programlar açılabilmekte, programların açılmasında öğretim üyesinin niteliği göz önüne alınmamakta, doktora programı açılacak ana bilim dallarında doçent ve profesör sayısı göz önüne alınmamaktadır. Enstitü ve programların açılmasının ölçütleri yeniden gözden geçirilerek düzenlenmeli, özellikle doktora programları yeterli sayıda öğretim elemanına ve alt yapı olanaklarına sahip üniversitelerde açılmalıdır. Her ne 
kadar Yüksek Öğretim Kurumu Üniversitelerin Lisansüstü programlarını açabilmeleri için belirli sayıda öğretim üyesi bulunması zorunluluğunu getirse de programın açılması için yeterli sayıya ulaşamayan ana bilim dalları diğer ana bilim dallarından öğretim üyelerini bir araya getirerek program açabilmekte, yeterli sayıya ulaşamayan programların diğer ana bilim dallarındaki öğretim üyelerinin kağıt üzerinde bir araya getirilmesi ile program açılabilmektedir. Enstitülerin statüsü değiştirilerek bilim insanı yetiştirmek için yeni politikalar belirlenmeli, yüksek lisans ve doktora programları yeniden değerlendirilmelidir. Yapılacak bu düzenlemeler eğitimin kalitesini arttırmaya ve üniversitelerin özgün bilim ve teknoloji üretme işlevlerini ön plana çıkarmaya yönelik olmalidir.

- Lisansüstü eğitimde yapılan tezlerin bilime yenilik getirmediği, birbirlerini yenilemekten öteye gitmediği, aynı alanlarda birden fazla benzer tezlerin yapıldığı görülmekte bu da lisansüstü eğitimin kalitesini düşürmektedir. Doktora programı bilim insanı yetiştirmeye yönelik, Yüksek Lisans programlarının ise akademik ve teorik çalışmalar ülke sorunlarını da ele alacak çalışmalar olmasına özen gösterilmelidir. Lisansüstü tezlerde yapılacak araştırmalar özgün olmalı, bilime yenilik getirmeli, tez çalışmalarının belirlenmesinde ülkemiz için öncelikli konulara önem verilmeli, tezlerin uluslararası düzeyde çalışmalar olması özendirilmeli, yurt dışında yayınlanmaları teşvik edilmeli bu koşulu sağlayan öğrenci ve tez yöneticileri ödüllendirilmelidir. Tez çalışmalarında araştırmaya dayalı ve ciddî derslerin işlendiği sistem oluşturulmalı, tez sonuçları mutlaka ulusal ve uluslararası dergilerde yayınlanmalıdır.

- Lisansüstü öğrencilerinin büyük bölümünü oluşturan araştırma görevlilerinin önemli sorunları bulunmaktadır. Araştırma görevliği çekiciliğini kaybetmiş olup, güvencesi bulunmamaktadır. Araştırma görevlileri akademik görevleri dışındaki işlerde kullanılmakta, maddi sorunları bulunmakta, özlük hakları, görev tanımındaki belirsizlik, kadro statüsü, özgür düşünme ve düşündüğünü ifade edebilme sorunları bulunmaktadır.

- Bu sorunlara ilave olarak; lisansüstü eğitimle ilgili yasal düzenlemelerin yetersizliği, yönetmeliklerin içeriğinin her sorunu çözebilecek kadar geniş düzenlenemeyişi, tez hazırlama süreçlerinin sağlıklı işletilememesi, seminer ve tez çalışmalarıyla ilgili kaynaklara yerel olarak arzu edildiği ölçüde ulaşılamayışı, öğretim üyelerinin danışmanlıklarının fazlalığı ve lisansüstü 
eğitim hizmetlerini diğer eğitim faaliyet ve hizmetleriyle birlikte yürütmeleri, fiziki alt yapı yetersizlikleri, öğrencilere sunulan sosyal, kültürel ve sportif faaliyet, kütüphane, rehberlik ve danışmanlık hizmetlerinin yetersizliği, lisansüstü eğitim kontenjanlarının talebi karşılayamayacak kadar az olması ve enstitü bütçelerinin yetersiz olması gibi sorunlar Türkiye'de lisansüstü eğitimin amaçlarına istenilen ölçüde ulaşmasına engel olabilecek niteliktedir (Karakütük vd.; 2008).

- Lisansüstü eğitim faaliyetlerini düzenlemek, koordine etmek ve yürütmekle yükümlü olan enstitüler, üniversitelerin mevcut yap1 ve işleyiş̧i içinde gereğince algılanıp yerli yerine oturtulmamıştır. Lisansüstü eğitimde yerleşik bir akademik standart oluşmamıştır (Arıc1; 1997).

$\mathrm{Bu}$ genel sorunların çözümlenebilmesi için, devletin siyaset üstü bir yaklaşımla lisansüstü eğitimle ilgili ulusal bilim ve teknoloji politikaları oluşturması ve bunun ciddiyetle uygulanmasını takip etmesi en önemli beklentidir. Böyle düzenleme lisansüstü eğitim birimlerini gerek üniversitelerin içinde gerekse mali konularda YÖK, Maliye Bakanlığı ve Sayıştay gibi kurumlarda belirli bir kimliğe ve saygınlığa kavuşturacaktır (Çakar; 1997).

Türker (2001) başarılı bir lisansüstü eğitimin etkin akademik değerlendirmeyle mümkün olabileceğini belirtmiştir. Bu amaçla veri toplamak ve bu verilerle lisansüstü eğitim arasındaki ilişkiyi değerlendirip gelecek için hedefleri saptaması, mevcut durumun ve ileriye yönelik yapılacakların belirlenmesi, değerlendirmenin yalnızca akademik ölçütlerde olmasının sağlaması, objektiviteye en fazla çabanın gösterilmesi, akademik değerlendirme sonucu ortaya çıkan sonuçların takvime bağlanarak uygulanmasının sağlaması gerekmektedir.

Türkiye'de öğretim üyesi sayısı yeterli ve alt yapısını tamamlamış olan gelişmiş yüksek öğretim kurumların, lisansüstü ağırlıklı eğitim yapan kurumlar haline getirilmesi sağlanarak lisansüstü öğrenim daha etkili ve verimli hale getirilmelidir. Programlarda gelişmiş teknolojik alt yapıyla etkin bir eğitim ve araştırma hizmeti verilmeli, çok sayıda niteliksiz doktora ve yüksek lisans öğrencisi yerine daha az ve nitelikli öğrenciye olanak sağlanmalıdır. Bu amaçla kalite ve verimliliğini kanıtlamış olan gelişmiş üniversiteler lisans öğrenci sayılarını azaltmalı ve onlara daha fazla olanaklar sağlayarak bu kurumların lisansüstü eğitim yapan kurumlar haline getirilmesi sağlanmalıdır. Bu kurumlarda görevlendirilecek öğretim üyelerinin bilimsel yetkinliğini 
kanıtlamış, nitelikli elemanlar olması sağlanmalıdır. Lisansüstü eğitim yapan kurumlarda kalite ölçümü ve akreditasyon yapılmalı, alt yapı olanakları sağlanmalı, yüksek nitelikli ve yeter sayıda öğretim elemanı yetiştirmek için önlemler alınmalı, lisansüstü eğitimin niteliği yükseltilmelidir. Lisansüstü eğitimle ilgili ölçütlerin belirlenmesi gerekli olup bu amaçla öğretim üyelerinin sahip olması gereken nitelikler belirlenmeli, lisansüstü programların açılabilmesi için gerekli koşullar yeniden gözden geçirilmelidir.

Lisansüstü eğitim her kademesinde önem kazanmakla birlikte bazı yazarlarca doktora eğitimi üniversitelerin akademik kişiliklerindeki en önemli göstergedir. Yükseköğretim kurumları, araştırma ve elit eğitim ağırlıklı kurumlar ve kitlesel eğitim yapan kurumlar olarak iki grupta irdelenmeli ve kurum içinde meritokratik yapı kurulmalıdır. Bu tür ayrım, kitlesel eğitim yapan kurumlarda hiç araştırma yapılmayacağ 1 anlamında alınmamalıdır. Bu alanlardaki kaynaklar ağırlıklı olarak elit eğitim ve araştırma ağırlıklı kurumlara tahsis edilmelidir. Kaynakların kıt olduğu yerlerde sonuç verebilecek, anlamlı politikalar uygulayabilmenin ön koşulunun, tercihler yapmak zorunluluğu olduğu unutulmamalıdır (Kozlu; 1994).

$\mathrm{Bu}$ programlara adayların kabul edilmelerinde uygulanan ölçüler, özellikle üniversite için bilim insanı yetiştirme sürecinin kalitesini de etkilemektedir (Demirtaslı; 2002). Lisansüstü eğitimin hedeflerine ulaşmasında öğretim üyesi ve öğrencilerin uyumlu şekilde çalışması beklenir. Bir çeşit usta çırak ilişkisini andıran bu süreçte, öğretim üyelerinin birlikte çalışacağı istenilen nitelikte ve nicelikte öğrencileri kendilerinin seçmeleri gerekmektedir (Bülbül; 2003). Lisansüstü eğitimin önemli bir işlevi, ülkenin gereksinimi olan bilim insanlarını yetiştirmesidir. Bilim insanını kaliteli bilim insanı yetiştireceğine göre, öncelikle üniversite ve yüksekokullarda öğretim elemanı olacak bilim insanlarının iyi seçilmesi gerekir (Bayrakçeken; 1977). Öğretim üyesi, ağır sorumluluğu olan "yüksek lisans" ve "doktora" programlarıla bilim insanını yetiştirme görevini yerine getirirken aynı zamanda bu sorumluluğun gerektirdiği mesleki etik davranışları hem kendisi benimsemeli ve uygulamalı hem de yetiştirdiği bilim insanının benimsemesini ve uygulamasını sağlamada rehberlik etmelidir (Erdem; 2007).

Bilim ve teknolojide ilerleme, bilime ve bilimcilerin yetişmesine verilen önem ve sağlanan koşullarla doğrudan ilgilidir. Bilim insanı yetiştirmenin önemli kaynağı olan üniversitelere yapılacak yatırımların yanı sıra bilim insanı 
adaylarının seçiminde kullanılacak objektif, uygun ve doğru ölçütlerin neler olacağı araştırmalara dayalı olarak belirlenmelidir. Ancak bu türden bir çaba Türkiye'nin bilim alanlarında gelişme yolunu açacaktır.

\section{5-SONUÇ}

Lisansüstü eğitim bilim insanı yetiştirme ve ulusal bilim politikasının yürütülmesindeki en önemli etmenlerden biri olarak kabul edilmektedir. Temel amac1; bilgiyi üreten, kullanan, eleştiren ve üreten bir düşünce tarzıyla problem çözebilecek nitelikte insan gücünü yetiştirmektir. Lisansüstü eğitimde; lisans eğitimine göre bireye daha kapsamlı bilimsel araştırmalar yapma, karmaşık sorunları çözebilme, mesleki alanlarda uzmanlaşma, bilgi üretebilme ve sentez yapabilme yöntem ve becerisi kazandırılmaya çalışılır. Günümüzde üniversitelere öğretim elemanı yetiştirmenin dışında, endüstriyel alanlarda ve diğer çalışma alanlarında iş edinmenin bir ön koşulu olarak yüksek lisans ve doktora derecesinin de aranır hale gelmesi, lisansüstü eğitime olan ihtiyacı daha da artırmıştır.

Üniversitelerin araştırma üniversitesi kimliğini kazanabilmesinde en önemli etken olan enstitülerinin önemi büyüktür. Toplumun yaşam standartlarının yükselmesini sağlayacak, dünya bilim ve teknoloji uygulamalarında söz sahibi olabilecek çalışmaların çoğu enstitüler tarafından yürütülmektedir.

Enstitülerin başlıca amacı, ana bilim dallarında öğrenimini sürdüren lisansüstü öğrencilerine; bilimsel araştırma yaparak bilgiye erişme, değerlendirme, derin bakış açısı ile irdeleyerek yorum yapma ve yeni sentezlere ulaşma yeteneğini kazandırmak, üniversite mezunlarının mesleklerinde uzmanlaşması, yeni alanlara yönelmesi, entelektüel gereksinimlerinin karşılanması ve akademik kariyere yönlendirilmelerini sağlamaktır.

Lisansüstü eğitim konusunda yaşanan sorunların çözümlenebilmesi için her şeyden önemlisi üniversite, enstitü, öğretim üyesi, öğrenci ve enstitü idari personeli ölçeğinde karşılaştırmalı ve kapsamlı araştırmalar yapılmalıdır. Lisansüstü eğitimin kalitesi ve performansının yükseltilmesi için tespit edilen sorunların ilgili mercilerce ivedilikle çözümlenmesine çalışılmalı, alt yapısı yeterli olmayan üniversitelerde yeterli alt yapı oluşuncaya kadar lisansüstü eğitim ve yeterliliğini ispat etmiş üniversitelerde yapılmalıdır ve lisansüstü eğitimin örgütlenmesi gözden geçirilmelidir. 
$\mathrm{Bu}$ doğrultuda yeterli fiziki altyapıya sahip bağımsız birimler halinde oluşturulan enstitülerde, fakültelerden bağımsız ve ülke genelinde standart ölçütlerle seçilmiş bir öğretim kadrosunun oluşturulması da enstitülerin üstlenmiş olduğu misyonu yerine getirebilmesi açısından son derece önemlidir. Etkin bir idari yapılanmayla birlikte böylesi bir oluşum, eğitim politikaları ve beklenen neticeleri itibariyle daha verimli sonuçlar doğurabilecektir.

Enstitülerin hedefleri ileri ve uluslararası düzeyde ülkenin dünya pazarlarındaki rekabet gücünü artıracak disiplinler arası araştırmacıları destekleyen, ulusal ve uluslararası niteliklere sahip öğretim üyesi ve toplum için üstün nitelikli profesyonel araştırmacılar yetiştiren bir programlar bütünü oluşturmak olmalıdır.

\section{KAYNAKLAR}

Alhas, A. (2006), Lisansüstü Eğitim Yapmakta Olan Milli Eğitim Bakanlığ1 Öğretmenlerinin Lisansüstü Eğitime Bakış Açıları (Ankara İli Örneği), Basılmamış Yüksek Lisans Tezi, Gazi Üniversitesi, Eğitim Bilimleri Enstitüsü, Ankara.

Arıcı, H. (2001), "Sosyal Bilimler Alanında Bilim Adamı YetiştirmeLisansüstü Eğitim", Bilim Adamı Yetiştirme-Lisansüstü Eğitim, TÜBA Yayını, Bilimsel Toplantılar Serisi No 7, ss. 53-64.

Bayrakçeken, F. (1977), Bilim Adamı Yetiştirmede Güçlükler ve Çözüm Yolları, Tübitak VI. Bilim Kongresi Bilim Adamı Yetiştirme Grubu Tebliğleri, Ankara.

Bülbül,T. (2003), “Ankara Üniversitesi, Eğitim Bilimleri Fakültesinde Görev Yapan Öğretim Üyelerinin Lisansüstü Öğretime Öğrenci Seçme Sürecine İlişkin Görüşleri”, Ankara Üniversitesi Eğitim Bilimleri Fakültesi Dergisi, Cilt, 36, Say1, 1-2, 167-174, Ankara.

Can, A.A., Can, Ü.K., Bağcı, H. (2009), "Lisansüstü Müzik Eğitimi Programlarıyla ve Gerçekleştirilen Araştırmalarla İlgili Sorunlar ve Çözüm Önerileri”, I. Uluslararası Türkiye Eğitim Araştırmaları Kongresi, 1-3 Mayıs 2009, Çanakkale.

Çakar, Ö. (1997), "Fen Bilimleri Alanında Bilim Adamı Yetiştirme: Lisansüstü Eğitim”, TÜBA Bilimsel Toplantı Serileri:7, ss. 65-75.

Demirtaşlı, N. (2002), "Lisansüstü Eğitim Programlarına Girişte Lisansüstü Eğitimi Giriş Sınavı (LES) Sonucunun ve Diğer Ölçütlerin 
Kullanımına İlişkin Bir Tarama”, Ankara Üniversitesi Eğitim Bilimleri Fakültesi Dergisi, Cilt: 35, Sayı: 1-2, ss. 61-70, Ankara.

Erdem A.R. (2007), "Öğretim Üyesinin Bilim İnsanı Yetiştirme Sorumluluğu ve Bu Sorumluluğun Gerektirdiği Mesleki Etik", Akademik Dizayn Dergisi 1(2), ss. 77-81.

Gök, T. ve Sılay, İ. (2005), "Lisansüstü Eğitime Yüksek Lisans ve Doktora Koşullarının İrdelenmesi Üzerine Bir Çalışma, Lisansüstü Eğitim”, Dokuz Eylül Üniversitesi Buca Eğitim Fakültesi Dergisi, Özel Sayı:1, 137-140.

Güven, İ. ve Tunç, B. (2007), "Lisansüstü Öğretim Öğrencilerinin Akademik Sorunları : Ankara Üniversitesi Eğitim Bilimleri Enstitüsü Örneği”, Eğitim Bilimleri, 173, ss. 157-171.

İnce, M. L. ve Korkusuz, F. (2006), Lisansüstü Eğitim Hedeflerini Geliştirmede Öğrenci Öğretim Üyesi Etkileşimi: Bir Disiplinin Farklı Üniversitelerde ve Farklı Disiplinlerin Bir Üniversitedeki Durumu, TÜBİTAK Sosyal ve Beşeri Bilimler Araştırma Grubu, Proje No:104K093, 2006.

Karakütük, K. (2002), Öğretim Üyesi ve Bilim İnsanı Yetiştirme-Lisansüstü Öğretimin Plânlanması (2.Bask1), Anı Yayıncılık, Ankara.

Karakütük, K., Aydın, A., Abalı, G., Yıldırım, S., (2008), "Lisansüstü Öğretimin Sorunları Konusunda Ankara'daki Üniversitelerin Lisansüstü Enstitü Yöneticilerinin Görüşleri”, Eğitim ve Bilim, cilt 33, say1 147, ss. 42-53.

Kaya, Y. K. (1989), İnsan Yetiştirme Düzenimiz, Bilim Yayınları, Ankara.

Kozlu,C. (1994), Türkiye Mucizesi İçin Vizyon Arayışları ve Asya Modelleri, Türkiye İs Bankası Kültür Yayınları Ankara.

Nayır, F. (2007), Ankara'da Eğitim Bilimleri Alanında Lisansüstü Öğrenim Görmekte Olan Öğretmen, Yönetici ve Müfettişlerin Sorunları (Yüksek Lisans Tezi). Üniversitesi Eğitim Bilimleri Enstitüsü Eğitim Bilimleri Anabilim Dalı Eğitim Yönetimi ve Teftişi Yüksek Lisans Program1, Ankara.

Ŏguzkan, F. (1981), Eğitim Terimleri Sözlüğü, TDK Yayınları, Ankara.

Sayan, Y. ve Aksu, H. (2005), "Akademik Personel Olmadan Lisansüstü Eğitim Yapan Bireylerin Karsılaştıkları Sorunlar Üzerine Nitel 
Çalışma, Lisansüstü Eğitim”, Dokuz Eylül Üniversitesi Buca Eğitim Fakültesi Dergisi, Özel Sayı:1, ss.59-66.

Sevinç, B. (2001), "Türkiye' de Lisansüstü Eğitim Uygulamaları, Sorunlar ve Uygulamalar", DEÜ Eğitim Fakültesi Dergisi, Cilt: 34, Sayı: 1, ss. $25-40$.

Tosun, İ. (2001), Açı1ış Konuşması, Bilim Adamı Yetiştirme Lisansüstü, Eğitim, Ankara: TÜBA Bilimsel Toplantı Serileri:7, ss.7-15.

Tuzcu, G. (2003), "Lisansüstü Öğretim İçin Yurtdışına Öğrenci Göndermenin Planlanması", Milli Eğitim Dergisi, ss.155-165.

Türker, K. (2001), Bilim İnsanı Yetiştirme: Dünyada ve Türkiye'de Lisansüstü Eğitim, TÜBA Bilimsel Toplantı Serileri 7, Ankara.

Varış, F. (1984), "Lisansüstü Düzeyde Eğitim Elemanı Yetiştirme”, Eğitim Bilimleri Sempozyumu, Ankara Üniversitesi. Eğitim Bilimleri Fakültesi Yayınları:136, ss. 49-54, Ankara.

Yılmaz, R. (2008), Türkiye'de Lisansüstü Öğrenim için Öğrenci Seçimi: Kara Harp Okulu Savunma Bilimleri Enstitüsünde Bir Uygulama, Kara Harp Okulu Savunma Bilimleri Enstitüsü Harekat Araştırması Ana Bilim Dalı, Basılmamış YL Tezi, 134 s, Ankara.

Yükseköğretim Kanunu, 2547 SK, Resmi Gazete, Sayı:17506. 